\title{
PRODUKSI MANGGIS PADA BEBERAPA KELOMPOK UMUR TANAMAN DAN FAKTOR-FAKTOR YANG MEMPENGARUHI PRODUKSI MANGGIS DI KABUPATEN SUKABUMI, JAWA BARAT
}

\author{
Utami Nuraniputri ${ }^{1}$, Heny Kuswanti S. Daryanto ${ }^{2}$, dan Kuntjoro ${ }^{3}$ \\ 1)Mahasiswa Program Magister Ilmu Ekonomi Pertanian, Sekolah Pascasarjana, Institut Pertanian Bogor \\ 2)Staf Pengajar Departemen Agribisnis, Fakultas Ekonomi dan Manajemen, Institut Pertanian Bogor \\ 3)Staf Pengajar Departemen Ekonomi Sumberdaya dan Lingkungan, Fakultas Ekonomi dan Manajemen, \\ Institut Pertanian Bogor \\ e-mail : 1)utaminuraniputri@gmail.com
}

\begin{abstract}
Mangosteen is one of the prospective horticultural commodities in Indonesia. Mangosteen has been set as national commodities in RUSNAS Buah (Fruit of the National Strategic Research) since 2000. Mangosteen production in Indonesia has increased rapidly. In 1997 the production of mangosteen in Indonesia amounted to 17475 tonnes and increased to 114755 tonnes in 2014. However, mangosteen production in Indonesia is not optimal, because the productivity is still low. The average Indonesian mangosteen tree can produce 30-50 kg of fruit per tree, lower than in Malaysia, Thailand and India were able to reach the 200-300 kg of fruit per tree. Mangosteen production centers in Indonesia are in the province of West Java, with a contribution of $41 \%$ of the total production of mangosteen in Indonesia in 2012. In West Java, mangosteen production centers scattered in Five Districts, namely Tasikmalaya, Subang, Sukabumi, Bogor and Ciamis Districts. Therefore, the purpose of this study was to analyze the level of production and the factors that affect the production of mangosteen in Sukabumi. The results showed that the production of mangosteen in Sukabumi is still low and has not reached the production target set by Direktorat Tanaman Buah. Factors that influence the production of mangosteen in Sukabumi are the number and ages of productive plants owned by farmers.
\end{abstract}

Keywords: mangostee cultivation, mangosteen production, production factors.

\section{PENDAHULUAN}

Manggis merupakan salah satu komoditas hortikultura yang prospektif untuk dikembangkan di Indonesia. Pemerintah telah menetapkan manggis sebagai komoditas unggulan nasional dalam RUSNAS Buah (Riset Unggulan Strategis Nasional Buah) sejak tahun 2000. Berdasarkan data BPS (2013), nilai ekspor manggis mencapai 9,64\% dari total ekspor buah-buahan Indonesia di tahun 2012, dengan nilai nilai ekspor manggis pada tahun 2010 sebesar US\$ 8.754.427 dan meningkat sebesar $189,87 \%$ menjadi US\$ 16.622.522 pada tahun 2012. Firdaus (2011) menyatakan bahwa, peluang ekspor manggis masih terbuka karena pasar buah-buahan termasuk manggis belum dibatasi oleh kuota.

Peningkatan permintaan manggis dipengaruhi oleh tingginya khasiat manggis di bidang pengobatan. Hasil penelitian
Permana, et al. (2012) menunjukan bahwa bubuk kulit buah manggis instan mengandung kadar alfa-mangostin sebesar $0,59 \mathrm{mg} / \mathrm{g}$, antosianin sebanyak $1,13 \mathrm{mg} / \mathrm{g}$, dan kadar fenolik sebesar $8,49 \mathrm{mg} / \mathrm{g}$ per satuan bobot sampel kering,sedangkan kapasitas antioksidannya sebesar 19,72 mg/g AEAC. Menurut Pasaribu et al (2013), pemberian ekstrak etanol kulit buah manggis dengan dosis $100 \mathrm{mg} / \mathrm{kg}$ BB memberikan hasil yang lebih baik terhadap penurunan kadar glukosa darah.

Berdasarkan data BPS (2014), produksi manggis di tahun 1997 sebesar 17.475 ton dan meningkat menjadi 114.755 ton di tahun 2014 dengan jumlah tanaman produktif mencapai 1.429.459 pohon. Namun produksi manggis di Indonesia belum optimal dan masih dapat ditingkatkan melalui peningkatan produktivitas tanaman manggis tersebut. Berdasarkan data BPS (2014) Produktivitas 
tanaman manggis di Indonesia pada tahun 2015 sebesar $75.51 \mathrm{~kg} /$ pohon, sedangkan menurut Setiawan et al. (2008), produktivitas tanaman manggis di Malaysia, Thailand dan India mencapai $200-300 \mathrm{~kg}$ buah per pohon. Hal tersebut disebabkan oleh budidaya tanaman manggis di Indonesia yang masih sangat tradisional, tanpa ada pemeliharaan, dan jarang dipupuk (Astuti 2012).

Sentra produksi manggis terbesar di Indonesia berada di Provinsi Jawa Barat. Berdasarkan data Badan Pusat Statistik (2013), konstribusi produksi manggis di Propinsi Jawa Barat terhadap produksi manggis nasional pada tahun 2012 adalah sebesar 41\%. Menurut Dinas Pertanian Tanaman Pangan Provinsi Jawa Barat (2012), keragaan tanaman manggis di daerah sentra khususnya di Jawa Barat umumnya masih ditanam pada lahan pekarangan dengan teknologi budidaya tradisional, dipelihara turun temurun dan sudah berumur puluhan tahun serta belum tersentuh oleh teknologi maju, sehingga produksi dan mutu buah manggis yang dihasilkan masih rendah.

Data Dinas Pertanian Tanaman Pangan Provinsi Jawa Barat (2012) menunjukkan bahwa sentra produksi manggis berasal dari Kabupaten Tasikmalaya, Subang, Sukabumi, Bogor dan Ciamis. Diantara kelima kabupaten tersebut, Kabupaten Sukabumi merupakan kabupaten yang sedang aktif meningkatkan produksi manggis. Selain itu, sentra perkebunan manggis di Sukabumi, tengah memasuki masa produktif dari pohon-pohon yang ditanam. Selama musim panen berlangsung, tingkat produksi bisa mencapai satu ton per hari. Masa paling produktif pohon manggis adalah saat berusia 20 hingga 30 tahun (Jaluardi, 2012).

Untuk meningkatkan produksi dan mutu manggis, Direktorat Budidaya Tanaman Buah (2009) menetapkan Standar Operasional Procedure (SOP) budidaya manggis, serta target peningkatan produksi. Target produksi manggis disajikan pada Tabel 1, sedangkan target mutu yang ditetapkan meliputi : buah utuh, tidak belah, pecah, atau terkelupas; jumlah bercak, memar, atau noda hitam pada pemukaan kulit buah berkurang; persentase buah layak ekspor meningkat 25-40\%, menurunnya tingkat serangan getah kuning dan burik buah; warna daging buah putih bersih; serta buah aman konsumsi.

Tabel 1. Target Produksi Manggis di Kabupaten Sukabumi

\begin{tabular}{c|c|c|c|}
$\begin{array}{c}\text { Umur } \\
\text { Tanaman }\end{array}$ & $\begin{array}{c}\text { Produksi } \\
\text { saat ini } \\
\text { (kg/pohon) }\end{array}$ & $\begin{array}{c}\text { Target } \\
\text { produksi } \\
\text { (kg/pohon) }\end{array}$ & $\begin{array}{c}\text { Target } \\
\text { produksi } \\
\text { per hektar } \\
\text { (ton) }\end{array}$ \\
\hline 8 & $10-15$ & $10-15$ & $1-1.5$ \\
10 & 30 & 30 & 3 \\
15 & $80-100$ & $80-100$ & $8-10$ \\
20 & $125-150$ & $125-150$ & $12.5-15$ \\
\hline 25 & 200 & 200 & 20 \\
\hline 30 & 250 & 250 & 25 \\
\hline
\end{tabular}

Sumber : Direktorat Budidaya Tanaman Buah (2009)

Tujuan penelitian ini adalah untuk mengetahui tingkat produksi manggis di Kabupaten Sukabumi, serta mempelajari faktor-faktor yang memepengaruhi produksi manggis di Kabupaten Sukabumi.

\section{KERANGKA TEORI}

Soekartawi (2002), menyatakan bahwa produksi adalah perubahan input atau output. Debertin (1986), mengungkapkan bahwa, dalam ekonomi produksi, produsen dalam upaya memaksimalkan profit menghadapi sejumlah pilihan yang kompleks. Produsen sebagaimana halnya konsumen juga menghadapi problem alokasi sumberdaya. Petani misalnya, harus memutuskan untuk mengalokasikan sejumlah sumberdaya lahan, tenaga kerja, beberapa macam input variabel dan peralatan yang dimilikinya untuk mengusahakan suatu komoditi.

Penambahan input produksi mengikuti hukum The law of diminishing marginal returns, yaitu jika jumlah input variabel ditambah penggunaannya, maka output yang dihasilkan meningkat tetapi setelah mencapai titik tertentu penambahan output semakin lama semakin berkurang. Berdasarkan fungsi produksi neoklasik, kurva total produksi dikategorikan menjadi tiga wilayah tahapan produksi (Gambar 1). 


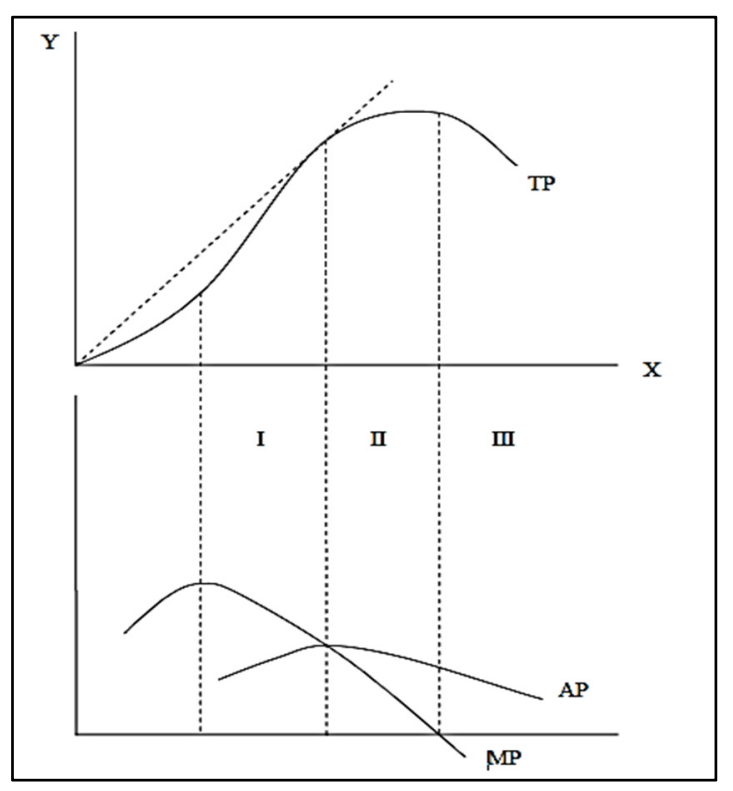

Gambar 1. Tahapan Produksi pada Fungsi Produksi Neoklasik

Sumber : Debertin 1986

Dimana :

TP : Total Product, merupakan produksi total yang menghasilkan oleh suatu proses produksi.

MP : Marginal Product, mengacu pada perubahan output yang diakibatkan oleh perubahan penggunaan satu satuan input.

AP : Average Product, merupakan perbandingan antara output dan input.

Daerah I dan III dikenal sebagai daerah irasional. Diistilahkan demikian sebab daerah produksi I dan III merepresentasikan level penggunaan input produksi yang tidak memaksimalkan keuntungan usahatani. Petani yang orientasi perilaku produksinya tidak merujuk pada konsep maksimalisasi keuntungan digolongkan sebagai petani yang tidak rasional. Daerah produksi II, seringkali diistilahkan sebagai daerah produksi yang ekonomis atau tahapan produksi rasional. Terminologi ini merepresentasikan perilaku petani yang rasional, dan selalu berusaha memaksimalkan keuntungan usahataninya (Debertin 1986).

Pada Gambar 1 terlihat bahwa kurva produksi bermula dari titik nol. Hal ini menunjukkan bahwa tidak ada satupun kontribusi variabel input maka tidak ada output yang dihasilkan. Bila proses produksi input termanfaatkan maka total produksi akan bergerak ke atas. Dengan bertambahnya input, kurva produksi total atau TP semakin meningkat tapi tambahannya atau MP mulai turun. Pola ini mengacu pada pertambahan hasil yang semakin menurun (The law of diminishing return). Saat AP meningkat, kurva produksi marginal bergerak meningkat dan melebihi besarnya produksi rata-rata. Pada MP dan AP berpotongan, merupakan awal dari tahap kedua dan produksi rata-rata mencapai puncak yang tertinggi. Pada produksi total mencapai titik puncak, kurva MP memotong sumbu horizontal dan selanjutnya mencapai nilai negatif. Penurunan total produksi menunjukkan bahwa semakin banyak input yang digunakan justru akan mengurangi produksi totalnya. Kondisi ini masuk pada tahap ketiga bahwa penambahan input menyebabkan penurunan produksi total.

Fungsi produksi merupakan suatu fungsi yang menunjukkan hubungan teknis antara hasil produksi fisik (output) dengan faktorfaktor produksi (input). Rumus matematis fungsi produksi dapat dituliskan sebagai berikut :

$$
\mathrm{Y}=\mathrm{f}(\mathrm{X} 1, \mathrm{X} 2, \mathrm{X} 3, \ldots \ldots \ldots \ldots \ldots \ldots . . . . \mathrm{Xn})
$$

Dimana :

$\mathrm{Y}=$ Jumlah produksi yang dihasilkan

$\mathrm{X}=$ Faktor produksi yang digunakan atau variabel yang mempengaruhi

Soekartawi (2003) menyatakan bahwa fungsi produksi linear menggambarkan hubungan yang bersifat linear antara peubah bebas $(\mathrm{X})$ dan peubah tidak bebas $(\mathrm{Y})$. Fungsi produksi linear dapat dibedakan menjadi dua yaitu fungsi produksi linear sederhana dan linear berganda. Fungsi produksi linear sederhana (simple regression) digunakan pada saat jumlah variabel faktor atau $X$ yang digunakan adalah satu, sehingga fungsi produksi linear yang digunakan dalam penelitian ini adalah fungsi produksi linear berganda.

Fungsi produksi Cobb-Douglas menurut Soekartawi (2003) adalah suatu fungsi atau 
persamaan yang melibatkan dua atau lebih variabel, dimana variabel yang satu disebut dengan variabel dependen $(\mathrm{Y})$, dan yang lain disebut sebagai variabel independen $(X)$. Penyelesaian hubungan antara $\mathrm{Y}$ dan $\mathrm{X}$ adalah biasanya dengan cara regresi dimana variasi dari $\mathrm{Y}$ akan dipengaruhi oleh variasi dari X. Parameter-parameter yang diperoleh dari model fungsi tersebut merupakan elastisitas produksi bagi setiap faktor produksi yang masuk dalam model dengan nilai elastisitas setiap faktor produksi dalam model ini dianggap tetap. Model fungsi produksi Cobb-Douglas hanya mampu menerangkan proses produksi pada fase diminising return, yaitu fase produksi pada saat tambahan produksi yang dihasilkan sebagai akibat adanya tambahan faktor produksi, meningkat dengan peningkatan yang semakin lama semakin berkurang.

Menurut Soekartawi (2003), bentuk umum model fungsi produksi Cobb-Douglas adalah sebagai berikut:

$$
\mathrm{Y}=\mathrm{bo} X 1^{\mathrm{b} 1} \mathrm{X} 2^{\mathrm{b} 2} \mathrm{X} 3^{\mathrm{b} 3} \ldots \ldots \ldots . . . \mathrm{Xn}^{\mathrm{bn}} \mathrm{e}^{\mathrm{u}}
$$

Dimana:

$\mathrm{Y}=$ Jumlah produksi yang diduga

bo $=$ Intersep

$b i=$ Parameter penduga variabel ke-i dan merupakan elastisitas

$\mathrm{X} i=$ Faktor produksi yang digunakan $(i=1$, $2,3, \ldots, n)$

$\mathrm{e}=$ Bilangan natural (2.718)

$\mathrm{u}=$ Kesalahan (disturbance term)

Pendugaan terhadap persamaan akan lebih mudah dilakukan jika persamaan diubah menjadi bentuk linear berganda dengan cara melogaritmakan persamaan tersebut. Logaritma dari persamaan tersebut adalah sebagai berikut:

$\log Y=b_{0}+b_{1} \log X+b_{2} \log X_{1}+\ldots . .+b_{n} \log X_{n}+u$ atau

$\ln Y=\ln b_{0} b_{1} \ln X_{1}+b_{2} \ln X_{2}+\ldots+b_{n} \ln X_{n}+u$

Nilai b1, b2, b3,....bn pada fungsi produksi Cobb-Douglas menunjukkan elastisitas $\mathrm{X}$ terhadap Y. Karena penyelesaian fungsi Cobb-Douglas selalu dilogaritmakan dalam bentuk fungsi linear, maka terdapat beberapa persyaratan yang harus dipenuhi dalam menggunakan fungsi Cobb-Douglas, yaitu: tidak ada nilai pengamatan yang bernilai nol, perlu asumsi bahwa tidak ada perbedaan teknologi, tiap variabel $\mathrm{X}$ adalah perfect competition, perbedaan lokasi seperti iklim sudah tercakup pada faktor kesalahan (u).

\section{METODOLOGI PENELITIAN WAKTU DAN TEMPAT PENELITIAN}

Penelitian dilaksanakan di Kecamatan Cikembar dan Kecamatan Cicantayan, Kabupaten Sukabumi, Provinsi Jawa Barat. Pemilihan lokasi dilakukan dengan pertimbangan bahwa Kabupaten Sukabumi merupakan salah satu sentra penghasil manggis di Jawa Barat dan 80 persen produksi manggis di Kabupaten Sukabumi berasal dari Kecamatan Cikembar dan Kecamatan Cicantayan (BPS Kabupaten Sukabumi 2013). Pengumpulan data primer dilaksanakan pada bulan AprilMei 2015.

\section{JENIS DAN SUMBER DATA}

Penelitian ini menggunakan data primer dan sekunder. Data primer diperoleh langsung dari petani menggunakan metode wawancara melalui pengisian kuisioner. Data sekunder yang digunakan pada penelitian ini diperoleh dari instansi terkait, seperti Direktorat Jendral Hortikultura, Badan Pusat Statistik Kabupaten Sukabumi, Dinas Pertanian Tanaman Pangan Kabupaten Sukabumi, Badan Pelaksana Penyuluhan Pertanian dan Kehutanan Kabupaten Sukabumi dan instansi lainnya yang terkait dengan produksi manggis.

\section{METODE PENARIKAN SAMPEL}

Populasi penelitian adalah petani Manggis di Kecamatan Cikembar dan Cicantayan Kabupaten Sukabumi. Total populasi mencapai 450 petani. Penentuan responden dilakukan melalui dua tahap yaitu 
teknik stratifikasi (stratified sampling) dan penarikan sampel secara acak (random sampling). Teknik stratifikasi digunakan untuk membagi populasi sesuai dengan umur tanaman di lokasi penelitian dan tahap selanjutnya menggunakan teknik pengambilan responden secara acak untuk mengambil responden pada setiap kelompok umur tanaman agar setiap penarikan responden dalam setiap kelompok mempunyai peluang yang sama untuk dipilih sebagai responden. Penentuan responden dengan teknik stratifikasi dilakukan karena umur tanaman diilokasi penelitian beragam, dan tingkat produksi tanaman dipengaruhi oleh umur tanaman, sehingga untuk menggambarkan keadaan populasi maka penentuan responden dilakukan menggunakan teknik stratifikasi.

Petani yang menjadi responden hanya petani yang memiliki umur pohon seragam, kalaupun terdapat perbedaan umur pada tanaman yang dimiliki petani responden, perbedaan umurnya hanya terdapat pada kelompok tanaman produktif dan tidak produktif, sehingga tidak terjadi bias dalam menghitung penerimaan petani berdasarkan umur tanaman.

Petani manggis pada penelitian ini dikelompokkan menjadi tiga bagian berdasarkan umur tanaman produktif yang dimiliki, yaitu kelompok pertama merupakan petani yang memiliki tanaman dengan rata-rata umur tanaman produktif di bawah 20 tahun (12 responden), kelompok kedua merupakan petani dengan tanaman produktif rata-rata berumur 20-30 (17 responden) tahun, dan yang terakhir merupakan petani yang tanamannya berusia di atas 30 tahun (20 responden). Pengelompokan umur dilakukan untuk melihat tingkat produksi manggis pada setiap kelompok umur tanaman, dan membandingkannya dengan target yang ditetapkan oleh Direktorat Budidaya Tanaman Buah.

\section{METODE ANALISIS}

Produksi adalah suatu kegiatan yang mengubah input menjadi output. Kegiatan tersebut dalam ekonomi biasa dinyatakan dalam fungsi produksi. Sedangkan fungsi produksi menurut Debertin (1986), menerangkan hubungan teknis yang mentransformasikan input atau sumberdaya menjadi output atau komoditas. Untuk menduga hubungan antara variabel bebas dengan variabel terikat, dan menganalisis faktorfaktor yang mempengaruhi produksi manggis di Kabupaten Sukabumi, digunakan model fungsi produksi Cobb-Douglas. Pendugaan parameter fungsi produksi dilakukan dengan metode kuadrat terkecil (Ordinary Least Square), dengan menggunakan program $S A S$ 9.0. Adapun fungsi produksi usahatani manggis di Kabupaten adalah sebagai berikut :

$$
\ln Y=\ln C_{o}+\sum_{k=1}^{5} d_{k} \ln X_{k}+\sum_{i=1}^{3} e_{i} D_{i}+u
$$

Keterangan :

Y : Produksi (kg)

Co : Intersep

$\mathrm{X}_{1}$ : Luas lahan (m2)

$\mathrm{X}_{2}$ : Jumlah tanaman produktif (pohon)

$\mathrm{X}_{3}$ : Tenaga Kerja (HOK)

$\mathrm{X}_{4}$ : Pupuk Kandang $(\mathrm{kg})$

$\mathrm{X}_{5}$ : Pengalaman berusahatani (tahun)

$\mathrm{D}_{1}$ : Dummy tingkat pendidikan petani, dimana :

$1=$ SLTP ke atas ( $>6$ tahun)

$0=\mathrm{SD}(\leq 6$ tahun $)$

$\mathrm{D}_{2}$ : Dummy umur tanaman, dimana :

$1=$ Tanaman berumur20-30 tahun

$0=$ Tanaman berumur $<20$ tahun dan $>30$ tahun

$\mathrm{D}_{3}$ : Dummy umur tanaman, dimana :

$1=$ Tanaman berumur $\geq 30$ tahun

$0=$ Tanaman berumur $<30$ tahun

\section{HASIL DAN PEMBAHASAN}

\section{GAMBARAN UMUM BUDIDAYA MANGGIS DI KABUPATEN SUKABUMI}

Tanaman manggis di Kabupaten Sukabumi umumnya diperbanyak menggunakan biji, dengan rata-rata umur tanaman lebih dari 20 tahun dan merupakan varietas lokal yang ditanam secara turun temurun. Pola penanaman yang diterapkan oleh petani manggis adalah tumpangsari. Tanaman pisang, singkong, serta sayuran, digunakan petani sebagai tanaman sela. Hal ini dilakukan untuk menambah penghasilan 
petani selama menunggu masa panen manggis tiba. Selain itu, penanaman tanaman sela pada tanaman manggis muda, memang dianjurkan oleh Direktorat Budidaya Tanaman Buah. Hal ini dimaksudkan sebagai naungan bagi tanaman manggis muda agar kelembaban tanah di sekitar tanaman terjaga. Tanaman sela yang dianjurkan adalah pisang, karena pisang mampu menyimpan cadangan air dalam jumlah besar pada batang dan akarnya.

Dalam membudidayakan tanaman, jarak tanam merupakan aspek yang penting untuk diperhatikan, karena dapat mempengaruhi produksi tanaman. Apabila jarak tanam terlalu rapat, dapat menimbulkan kompetisi antar tanaman dalam mendapatkan zat hara di dalam tanah, sedangkan bila jarak tanam terlalu renggang maka akan terjadi inefisiensi dalam penggunaan lahan. Menurut Direktorat Budidaya Tanaman Buah (2009), jarak tanam ideal untuk manggis adalah $10 \mathrm{x}$ $10 \mathrm{~m}$ atau $8 \times 10 \mathrm{~m}$. Dengan jarak tanam tersebut, diperlukan 100-125 bibit per hektar.

Namun 75.51 persen petani manggis di Kabupaten Sukabumi belum menerapkan penggunaan jarak tanam tersebut. Hal ini dikarenakan saat tanaman mereka ditanam, belum ada anjuran mengenai jarak tanam ideal untuk manggis. Sehingga petani menanam manggis dengan jarak tanam yang rapat, yaitu $6 \times 6 \mathrm{~m}$, dengan harapan bahwa semakin banyak manggis yang ditanam maka hasil yang diperoleh akan semakin tinggi. Pemerintah pun menyarankan untuk menebang sebagian pohon manggis yang terlalu rapat agar tidak terjadi kompetisi dalam penyerapan hara didalam tanah, sehingga dapat meningkatkan produktivitas manggis. Namun petani tidak menerapkannya karena beranggapan bahwa dengan menebang sebagian pohon, maka pendapatannya akan berkurang.

Kegiatan pemeliharaan tanaman manggis yang dilakukan petani meliputi kegiatan penyiangan, pemangkasan, pembersihan kebun dan pemupukan. Kegiatan penyiangan, pembersihan kebun dan pemangkasan umunya hanya dilakukan satu kali setahun ketika menjelang ataupun saat masa panen tiba.

\section{PENGGUNAAN SARANA PRODUKSI DALAM USAHATANI MANGGIS}

Pada bagian ini akan dijelaskan penggunaan sarana produksi yang digunakan dalam usahatani Manggis. Jenis sarana produksi yang digunakan antara lain pupuk, tenaga kerja dan alat-alat pertanian.

\section{Penggunaan Pupuk}

Pupuk yang digunakan oleh petani responden adalah pupuk kandang dan pupuk NPK. Namun umumnya petani hanya menggunakan pupuk kandang pada tanaman Manggisnya. Ada 73.5 persen petani yang hanya menggunakan pupuk kandang, 14.3 persen petani menggunakan campuran pupuk kandang dan pupuk NPK, 4.1 persen responden menggunakan pupuk NPK saja, sedangkan sisanya tidak memberikan pupuk apapun pada tanamannya. Petani lebih memilih menggunakan pupuk kandang dikarenakan sifat pupuk kandang yang tidak hanya memenuhi kebutuhan nutrisi tanaman, tetapi juga dapat menggemburkan dan memperbaiki tekstur tanah. Pupuk kandang yang digunakan petani tersebut dibeli dari peternak setempat ataupun kios penjualan sarana produksi pertanian yang ada. Menurut Marsono dan Sigit (2001) pupuk kandang aman digunakan dalam jumlah besar untuk beragam jenis tanaman buah, bahkan dalam pertanian organik sumber utama hara berasal dari pupuk kandang.

Dosis penggunaan pupuk kandang yang diberikan oleh tiap-tiap petani berbeda-beda. Berkisar antara 3 hingga 150 kilogram per pohon per tahun. Sedangkan untuk pupuk NPK, dosis yang diberikan petani berkisar antara 0.3 hingga 3 kilogram per pohon per tahun. Hal ini tergantung dari sumberdaya yang dimiliki oleh masing-masing petani responden. Sedangkan dosis penggunaan pupuk yang sesuai dengan SOP yang dianjurkan oleh Direktorat Budidaya Tanaman Buah (2009) untuk tanaman 
berumur 4 tahun keatas adalah campuran urea, SP-36 dan $\mathrm{KCl}$ (1:4:3) sebanyak 3-6 kg per pohon ditambah pupuk kandang $40 \mathrm{~kg}$ per pohon, pemupukan diberikan dengan frekuensi dua kali per tahun. Namun rata-rata petani melakuan pemupukan 1 kali setahun, yaitu setelah musim panen selesai.

Tabel 2. Penggunaan Pupuk Berdasarkan Umur Tanaman pada Usahatani Manggis di Kabupaten Sukabumi Tahun 2015

\begin{tabular}{|c|c|c|c|}
\hline \multirow{2}{*}{ Jenis Pupuk } & \multicolumn{3}{|c|}{$\begin{array}{l}\text { Penggunaan Pupuk } \\
\text { (kg/hektar) }\end{array}$} \\
\hline & $\begin{array}{l}<20 \\
\text { tahun }\end{array}$ & $\begin{array}{c}20-30 \\
\text { tahun }\end{array}$ & $\begin{array}{c}>30 \\
\text { tahun }\end{array}$ \\
\hline $\begin{array}{l}\text { Pupuk } \\
\text { Kandang }\end{array}$ & 2861.25 & 5926.47 & 2013.63 \\
\hline Pupuk NPK & 25.74 & 12.16 & 18.95 \\
\hline
\end{tabular}

Data mengenai penggunaan pupuk kandang dan pupuk NPK untuk tanaman manggis di Kabupaten Sukabumi terdapat pada Tabel 2. Penggunaan pupuk kandang tertinggi terdapat pada kelompok tanaman berumur 20-30 tahun, yaitu $5926.47 \mathrm{~kg}$ pupuk per hektar per tahun. Sedangkan pada pupuk NPK, penggunaan pupuk tertinggi terdapat pada kelompok tanaman berumur kurang dari 20 tahun, yaitu $25.74 \mathrm{~kg}$ per hektar per tahun.

\section{Penggunaan Tenaga Kerja}

Tenaga kerja yang digunakan pada usahatani Manggis terdiri dari Tenaga Kerja Dalam Keluarga (TKDK) dan Tenaga Kerja Luar Keluarga (TKLK). Jumlah tenaga kerja yang digunakan dalam analisis usahatani Manggis menggunakan satuan HOK (Hari
Orang Kerja). Jumlah jam kerja di lokasi berkisar delapan jam per hari. Jam kerja dimulai dari pukul 07.00-12.00 kemudian dilanjutkan pada pukul 13.00-16.00 yang dihitung sebagai satu HOK. Upah untuk satu HOK di lokasi penelitian sebesar Rp 75.000.

Pada Tabel 3 dijabarkan data mengenai kebutuhan tenaga kerja pada usahatani manggis di Kabupaten Sukabumi tahun 2015. Berdasarkan data pada tabel tersebut, pemanenan merupakan kegiatan yang paling banyak membutuhkan tenaga kerja. Hal tersebut terjadi karena sifat pemanenan manggis berlangsung setiap dua hari sekali selama dua bulan musim panen. Jadi, umumnya selama satu musim panen, panen dilakukan sebanyak 30 kali. Penyebab lain dari tingginya kebutuhan tenaga kerja untuk pemanenan adalah cara pemanenan yang masih tradisional menggunakan galah bambu, menyebabkan pemanenan membutuhkan tenaga kerja lebih banyak.

Data Tabel 3 menunjukkan bahwa pada kelompok umur tanaman di bawah 20 tahun, penggunaan tenaga kerja lebih tinggi dibandingkan dengan kelompok umur lainnya. Penggunaan Tenaga Kerja Luar Keluarga (TKLK) pada tanaman berumur kurang dari 20 tahun, 20-30 tahun, dan lebih dari 30 tahun berturut-turut adalah 83 persen, 82 persen dan 98 persen dari total kebutuhan tenaga kerja dalam usahatani manggis. Hal ini menunjukkan bahwa keberadaan usahatani manggis menguntungkan bagi masyarakat disekitar kebun manggis karena dapat menyerap banyak tenaga kerja.

Tabel 3. Penggunaan Tenaga Kerja Berdasarkan Umur Tanaman pada Usahatani Manggis di Kabupaten Sukabumi Tahun 2015

\begin{tabular}{|c|c|c|c|c|c|c|c|c|c|}
\hline \multirow{2}{*}{ Kegiatan } & \multicolumn{3}{|c|}{$<20$ tahun } & \multicolumn{3}{|c|}{ 20-30 tahun } & \multicolumn{3}{|c|}{$>30$ tahun } \\
\hline & DK & LK & Total & DK & LK & Total & DK & LK & Total \\
\hline Pemupukan & 2.7 & 7.5 & 10.1 & 3.9 & 6.9 & 10.8 & 0.2 & 9.4 & 9.6 \\
\hline Pemangkasan & 3.0 & 13.9 & 16.9 & 5.5 & 9.4 & 14.9 & 0.2 & 10.2 & 10.4 \\
\hline Pemanenan & 29.6 & 152.3 & 181.9 & 23.4 & 133.0 & 156.4 & 3.3 & 140.6 & 143.9 \\
\hline Total & 35.3 & 173.7 & 209.0 & 32.7 & 149.3 & 182.1 & 3.7 & 160.1 & 163.8 \\
\hline Persentase (\%) & 16.9 & 83.1 & 100.0 & 18.0 & 82.0 & 100.0 & 2.3 & 97.7 & 100.0 \\
\hline
\end{tabular}




\section{Penggunaan Alat Pertanian}

Alat-alat pertanian yang digunakan pada usahatani Manggis antara lain adalah cangkul, parang, keranjang dan galah. Peralatan yang digunakan oleh petani responden adalah milik sendiri. Petani tidak selalu membeli alat-alat pertanian yang mereka gunakan di setiap musim panen, hal ini dikarenakan alat pertanian tersebut masih dapat digunakan lebih dari satu kali musim panen. Penggunaan alat pertanian pada usahatani manggis di Kabupaten Sukabumi dapat dilihat pada Tabel 4.

Tabel 4. Penggunaan Alat Pertanian pada Usahatani Manggis di Kabupaten Sukabumi Tahun 2015

\begin{tabular}{|l|c|c|}
\hline \multicolumn{1}{|c|}{ Jenis Alat } & Satuan & Jumlah \\
\hline Cangkul & Buah & 2 \\
\hline Sprayer & Buah & 1 \\
\hline Ember & Buah & 1 \\
\hline Arit & Buah & 2 \\
Galah & Buah & 2 \\
\hline Garpu & Buah & 1 \\
\hline Keranjang Bambu & Pasang & 4 \\
\hline
\end{tabular}

\section{PRODUKSI MANGGIS DI KABUPATEN SUKABUMI}

Hasil pengamatan terhadap produksi manggis di Kabupaten Sukabumi pada tahun 2015 dapat dilihat pada Tabel 5. Perhitungan produksi manggis didasarkan pada total produksi manggis per pohon selama musim panen berlangsung. Musim panen manggis terjadi satu kali setahun. Musim panen manggis berlangsung selama dua bulan, antara bulan Februari - April. Pemanenan dilakukan setiap dua hari sekali selama musim panen tersebut.

Pada Tabel 5 dapat terlihat bahwa produksi tanaman manggis di lokasi penelitian belum mencapai target produksi yang ditetapkan oleh Direktorat Tanaman Buah pada tahun 2009. Beberapa faktor penyebab tidak tercapainya target produksi yang ditetapkan adalah karena kurangnya penerapan SOP dalam pemeliharaan tanaman. Sebagai contoh, kegiatan pemupukan seharusnya dilakukan dua kali setahun dengan dosis campuran urea, SP-36 dan $\mathrm{KCl}$ (1:4:3) sebanyak 3-6 kilogram per pohon ditambah 40 kilogram per pohon pupuk kandang, dengan frekuensi pemupukan dua kali setahun, yaitu sebelum dan sesudah musim panen. Namun kenyataannya rata-rata petani hanya memberikan pupuk dengan dosis 0.15 kilogram pupuk NPK per pohon dan 27.2 kilogram pupuk kandang dengan frekuensi pemupukan satu kali setahun, setelah panen.

Selain itu, kegiatan pemangkasan pun tidak dilakukan sesuai dengan anjuran. Pemangkasan seharusnya dilakukan dua kali dalam setahun, namun petani umumnya hanya melakukan pemangkasan 1 kali setahun, bahkan tidak dilakukan pemangkasan sama sekali. Alasan minimnya penerapan SOP dalam budidaya Manggis di lokasi penelitian adalah karena petani merasa bahwa dengan pemeliharaan yang minim pun usaha tani manggis sudah menguntungkan, sehingga mereka tidak merasa perlu untuk menerapkan SOP yang telah dinjurkan oleh Direktorat Budidaya Tanaman Buah.

\section{FAKTOR-FAKTOR YANG MEMPENGARUHI PRODUKSI MANGGIS DI KABUPATEN SUKABUMI}

Analisis faktor-faktor yang mempengaruhi produksi dilakukan untuk melihat seberapa besar pengaruh suatu faktor produksi terhadap tingkat produksi suatu komoditas.

Tabel 5. Produksi Manggis di Kabupaten Sukabumi Tahun 2015

\begin{tabular}{|l|c|c|c|c|} 
Umur Tanaman & $\begin{array}{c}\text { Produksi per } \\
\text { pohon (kg) }\end{array}$ & $\begin{array}{c}\text { Jumlah } \\
\text { tanaman per } \\
\text { hektar (pohon) }\end{array}$ & $\begin{array}{c}\text { Produksi per } \\
\text { hektar (ton) }\end{array}$ & $\begin{array}{c}\text { Target Produksi } \\
\text { (ton) }\end{array}$ \\
\hline$<20$ tahun & 58.33 & 109 & 5.83 & $8-15$ \\
20-30 tahun & 134.11 & 155 & 13.41 & $15-25$ \\
\hline >30 tahun & 204.00 & 108 & 20.40 & $>25$ \\
\hline
\end{tabular}


Pada penelitian ini model fungsi produksi yang digunakan adalah fungsi Cobb-Douglas. Model dianalisis dengan analisis regresi berganda menggunakan metode OLS (Ordinary Least Square). Pengolahan data dilakukan dengan bantuan program SAS 9.1. Beberapa faktor yang diduga mempengaruhi produksi manggis adalah :

\section{Luas Lahan $\left(X_{1}\right)$}

Luas lahan pertanian yang digunakan untuk budidaya manggis merupakan penentu yang mempengaruhi produksi manggis. Secara umum semakin luas lahan yang digarap/ditanami, semakin besar jumlah produksi yang dihasilkan oleh lahan tersebut. Ukuran lahan yang digunakan dalam penelitian ini adalah hektar. Lahan yang diperhitungkan adalah lahan yang sudah menghasilkan.

\section{Jumlah Tanaman Produktif $\left(X_{2}\right)$}

Jumlah tanaman produktif yang dimiliki petani akan sangat mempengaruhi hasil produksi, semakin banyak jumlah tanaman produktif maka akan semakin besar produksi.

\section{Tenaga Kerja $\left(X_{3}\right)$}

Secara umum semakin banyak tenaga kerja yang dilibatkan dalam proses produksi usahatani maka akan semakin besar jumlah yang diproduksi atau dihasilkan. Untuk memudahkan penghitungan jumlah tenaga kerja yang dibutuhkan dalam proses produksi, digolongkan dalam satuan unit kerja Hari Orang Kerja (HOK), dimana satu HOK adalah setara dengan delapan jam bekerja per hari. Nilai satu unit HOK dihitung dengan upah setara kerja pria.

\section{Penggunaan Pupuk Kandang $\left(X_{4}\right)$}

Penggunaan pupuk kandang diasumsikan akan meningkatkan produksi manggis. Sebagian petani di lokasi penelitian hanya menggunakan pupuk kandang. Petani beranggapan bahwa penggunaan pupuk kandang tidak hanya dapat meningkatkan produksi manggis, tapi juga dapat memperbaiki struktur tanah.

\section{Pengalaman Petani $\left(X_{5}\right)$}

Pengalaman petani dalam usahatani manggis akan menentukan hasil produksi. Asumsinya adalah semakin berpengalaman petani dalam usahatani manggis maka akan semakin tinggi produksi usahataninya.

\section{Lama Pendidikan Petani $\left(D_{1}\right)$}

Lama pendidikan petani dikategorikan menjadi dua kelompok yang kemudian dijadikan sebagai variabel dummy dalam model. Kelompok pertama adalah petani berpendidikan SD dan tidak tamat SD (lama pendidikan $\leq 6$ tahun) dan kelompok kedua adalah petani yang berpendidikan SD ke atas (lama pendidikan $>6$ tahun). Asumsi dalam analisis bahwa pendidikan petani berpengaruh positif terhadap hasil produksi usahatani manggis. Artinya tingkat pendidikan petani yang lebih tinggi dari 6 tahun akan memberikan hasil produksi usahatani yang lebih besar dan variabel dummy-nya diberi bobot 1 (satu), sedangkan yang tamat SD ke bawah dibobot 0 (nol) karena diasumsikan memberikan hasil produksi usahatani yang lebih kecil.

\section{Umur Tanaman $\left(D_{2}\right.$ dan $\left.D_{3}\right)$}

Umur tanaman merupakan unsur penting dalam pengusahaan tanaman tahunan seperti manggis, hal tersebut berkaitan dengan sifat agronomis tanaman dimana suatu tanaman memiliki masa tertentu untuk berproduksi optimal. Asumsinya adalah semakin berumur tanaman maka semakin meningkat produksinya. Manggis mulai berproduksi setelah berumur minimal 10 tahun, dengan masa hidup bisa lebih dari 100 tahun tergantung pada pemeliharaan. Pada penelitian ini, umur tanaman dibagi menjadi tiga kelompok, yaitu tanaman berumur kurang dari 20 tahun, 20-30 tahun dan lebih dari 30 tahun, sehingga varabel dummy umur tanaman dibuat dalam dua tahap, yaitu :

$\mathrm{D}_{2}$ : Dummy umur tanaman, dimana :

$1=$ Tanaman berumur 20-30 tahun

$0=$ Tanaman berumur $<20$ tahun dan $>30$ tahun 
$\mathrm{D}_{3}$ : Dummy umur tanaman, dimana :

$1=$ Tanaman berumur $>30$ tahun

$0=$ Tanaman berumur $<30$ tahun

Hasil pendugaan parameter model fungsi produksi manggis dapat dilihat pada Tabel 8. Dari hasil pendugaan model ditunjukkan bahwa nilai koefisien determinasi $\left(R^{2}\right)$ sebesar 95.97 persen.Nilai koefisien determinasi tersebut menunjukkan bahwa sebesar 95.97 persen variasi produksi dapat dijelaskan secara bersama-sama oleh faktor luas lahan, jumlah tanaman, tenaga kerja, penggunaan pupuk kandang, pengalaman beruasahatani, umur tanaman, serta pendidikan petani. Lalu sisanya dipengaruhi oleh faktor lain di luar model.

Nilai parameter dugaan juga merupakan nilai elastisitas produksi yang menunjukkan perubahan produksi akibat adanya perubahan pada input. Hasil pendugaan model fungsi produksi manggis menunjukkan bahwa variabel luas lahan $\left(X_{1}\right)$ tidak berpengaruh signifikan pada keragaman produksi manggis. Hal ini di karenakan kerapatan tanaman pada masing-masing petani berbeda dan pada kebun petani juga ditanami tanaman lainnya, tidak hanya tanaman manggis saja.

Tabel 6. Hasil Pendugaan Parameter Model Fungsi Produksi Manggis di Kabupaten Sukabumi Tahun 2015

\begin{tabular}{|l|l|}
\multicolumn{1}{|c|}{ Variabel Bebas } & $\begin{array}{c}\text { Parameter } \\
\text { Dugaan }\end{array}$ \\
\hline Intersep atau Konstanta & 3.429 \\
\hline Luas Lahan $\left(\mathrm{X}_{1}\right)$ & 0.078 \\
\hline Jumlah Tanaman $\left(\mathrm{X}_{2}\right)$ & $1.044^{* * *}$ \\
\hline Tenaga Kerja $\left(\mathrm{X}_{3}\right)$ & -0.040 \\
\hline Pupuk Kandang $\left(\mathrm{X}_{4}\right)$ & -0.007 \\
\hline Pengalaman usahatani $\left(\mathrm{X}_{5}\right)$ & -0.039 \\
\hline Dummy Pendidikan $\left(\mathrm{D}_{1}\right)$ & 0.047 \\
\hline Dummy Umur Tanaman $\left(\mathrm{D}_{2}\right)$ & $0.904^{* * *}$ \\
\hline Dummy Umur Tanaman $\left(\mathrm{D}_{3}\right)$ & $1.355^{* * *}$ \\
\hline F-Hitung & 119.01 \\
\hline Koefisien Determinasi $(\mathrm{R} 2)$ & 0.9597 \\
\hline *** : Signifikan pada a 1 persen &
\end{tabular}

Jumlah tanaman produktif $\left(\mathrm{X}_{2}\right)$ berpengaruh nyata pada a satu persen dengan nilai parameter dugaan 1.04. Artinya setiap penambahan tanaman produktif sebanyak satu persen akan meningkatkan produksi sebesar 1.04 persen. Variabel tenaga kerja $\left(X_{3}\right)$ dan penggunaan pupuk $\left(\mathrm{X}_{4}\right)$ memiliki nilai dugaan parameter negatif, namun hal tersebut tidak berpengaruh signifikan terhadap keragaman produksi tanaman. Hal ini diduga karena pola tanaman manggis secara tumpangsari dengan tanaman lainnya, sehingga tenaga kerja dan pupuk tidak sepenuhnya digunakan untuk tanaman manggis. Selain itu, variabel pengalaman petani $\left(X_{5}\right)$ pun memiliki nilai parameter dugaan negatif, Hal ini dipengaruhi oleh kegiatan budidaya serta penguasaan teknologi oleh petani. Umumnya petani yang pengalaman usahataninya lebih lama, kurang menerapkan kegiatan budidaya yang intensif dan kurang menguasai teknologi baru sehingga berdampak negatif terhadap produksi.

Variabel dummy pendidikan petani $\left(\mathrm{D}_{1}\right)$ memiliki nilai parameter 0.047 , menunjukkan bahwa peningkatan pendidikan formal yang dimiliki petani dapat membantu meningkatkan produksi manggis. Hal tersebut dapat disebabkan oleh lebih terkelolanya manajemen budidaya tanaman apabila petani memiliki pendidikan yang lebih tinggi, Selain itu, petani yang lebih berpendidikan akan lebih mudah untuk menerapkan teknologi baru dalam budidaya sehingga dapat mendorong peningkatan produksi. Variabel dummy umur tanaman $\left(\begin{array}{lll}\mathrm{D}_{2} & \text { dan } & \mathrm{D}_{3}\end{array}\right)$ berpengaruh signifikan pada taraf satu persen. Hal tersebut menunjukkan bahwa terdapat keragaman produksi yang nyata antara tanaman berumur kurang dari 20 tahun, tanaman yang berumur 20-30 tahun dan tanaman yang berumur lebih dari 30 tahun.

\section{KESIMPULAN DAN SARAN}

\section{KESIMPULAN}

Kesimpulan yang diperoleh dari penelitian ini adalah, Tingkat produksi 
manggis di Kabupaten Sukabumi masih dapat ditingkatkan dan belum mencapai target produksi yang ditetapkan oleh Direktorat Tanaman Buah. Hal tersebut disebabkan oleh penerapan budidaya manggis yang belum sesuai dengan SOP yang dianjurkan oleh Direktorat Tanaman buah, seperti kurangnya pemeliharaan tanaman dan kebun, penggunaan pupuk di bawah dosis yang dianjurkan, serta bibit yang ditanaman bukan merupakan bibit unggul. Faktor-faktor yang secara signifikan berpengaruh positif terhadap produksi manggis adalah jumlah tanaman serta umur tanaman produktif yang dimiliki petani.

\section{SARAN}

Peningkatan produksi manggis dapat dilakukan melalui penerapan SOP budidaya manggis seperti mananam bibit unggul, melakukan pemupukan dengan dosis dan cara pemupukan yang sesuai anjuran, serta rutin melakukan kegiatan pemeliharaan dan pemangkasan tanaman sebanyak dua kali setiap tahunnya. Kegiatan pemangkasan ini penting dilakukan sebab dapat mempermudah proses pemanenan, sehingga dapat meminimalisir kerusakan buah dan tanaman saat pemanenan. Selain itu, pada tanaman yang rutin dipangkas, bobot buah yang dihasilkan lebih besar.

\section{DAFTAR PUSTAKA}

Astuti, R. 2012. Pengembangan Rantai Pasok Buah Manggis di Kabupaten Bogor, Jawa Barat [Disertasi]. Bogor: Sekolah Pascasarjana. Intitut Pertanian Bogor.

[BPS] Badan Pusat Statistik. 2014. Statistik Indonesia. Jakarta : BPS

[BPS] Badan Pusat Statistik. 2014. Statistik Tanaman Buah-buahan dan Sayuran Tahunan Indonesia 2014. Jakarta : BPS

[BPS Kabupaten Sukabumi] Badan Pusat Statistik Kabupaten Sukabumi. 2013. Kabupaten Sukabumi dalam Angka. Sukabumi : BPS Sukabumi.
Debertin, D.L. 1986. Agricultural Production Economics. New York : Macmillan Publishing Company.

[Diperta Jabar] Dinas Pertanian Tanaman Pangan Jawa Barat. 2012. Wilayah Sentra dan Produksi Buah Tahun 2011. Bandung. Tersedia pada : http:/ / diperta.jabarprov.go.id/index. php/subMenu/1429 [Diunduh pada : 20 April 2014]

[DPTB] Direktorat Budidaya Tanaman Buah. 2009. Standard Operating Procedure Manggis Kabupaten Sukabumi. Jakarta : Direktorat Budidaya Tanaman Buah. Direktorat Jendral Hortikultura. Departemen Pertanian.

Firdaus, D. 2011. Manggis. Bandung. Tersedia pada

http:/ /jabar.litbang.deptan.go.id/ind/ index.php/info-teknologi/14-alsin/64manggis-garcinia-mangostana-1-

[Diunduh pada : 20 April 2014]

Jaluardi, H. 2012. Sentra manggis Sukabumi memasuki masa produktif. Sukabumi. Tersedia pada : http:/ / regional.kompas.com/read/20 12/01/25/23235731/Sentra.Manggis.S ukabumi.Masuki.Masa.Produktif [Diunduh pada : 3 Juni 2014].

Marsono dan P Sigit. 2001. Pupuk Akar : Jenis dan Aplikasi. Jakarta: Penebar Swadaya

Pasaribu, F., P.Sitorus, dan S.Bahri. 2012. The Test of Ethanol Extract of Mangosteen Rind (Garcinia mangostana L.) to Decrease Blood Glucose Level. Journal of Pharmaceutics and Pharmacology Vol 1: 1-8

Permana, A.W., A.M.Widyanti, S.Prabawati, dan D.A. Setyabudi. 2012. Sifat Antioksidan Bubuk Kulit Buah Manggis (Garcinia Mangostana 1.) Instan dan Aplikasinya Untuk Minuman Fungsional Berkarbonasi. Jurnal Pascapanen Vol 9 No.2 : 88-95.

Setiawan, E., R. Poerwanto. 2008. Produktivitas dan Kualitas Buah Manggis di Purwakarta. Agrovigor Vol 1 No.1 : 12-19 
Soekartawi. 2002. Analisis Usahatani. Penerbit Universitas Indonesia (UI-Press). Jakarta.

Soekartawi. 2003. Teori Ekonomi Produksi Dengan Pokok Bahasan Analisis Fungsi Cobb-Douglas. Jakarta (ID): Raja Grafindo Persada. 